\begin{tabular}{rl|l}
$\begin{array}{c}\text { Cellular Physiology } \\
\text { and Biochemistry }\end{array}$ & \begin{tabular}{l} 
Cell Physiol Biochem 2012;30:450-457 \\
\cline { 2 - 3 } DOI: 10.1159/000339038
\end{tabular} & $\begin{array}{l}\text { O 2012 S. Karger AG, Basel } \\
\text { www.karger.com/cpb }\end{array}$ \\
\cline { 2 - 3 } & Published online: July 06, 2012 & $1015-8987 / 12 / 0302-0450 \$ 38.00 / 0$
\end{tabular}

\title{
Cellular Heat Acclimation Regulates Cell Growth, Cell Morphology, Mitogen- activated Protein Kinase Activation, and Expression of Aquaporins in Mouse Fibroblast Cells
}

\author{
Naotoshi Sugimoto ${ }^{1 *}$ Osamu Shido ${ }^{2}$ Kentaro Matsuzaki ${ }^{2}$ Takako Ohno-Shosaku \\ Yoshiaki Hitomi ${ }^{4}$ Masao Tanaka ${ }^{5}$ Toshioki Sawaki $^{5}$ Yoshimasa Fujita ${ }^{5}$ Takanori \\ Kawanami $^{5}$ Yasushi Masaki ${ }^{5}$ Toshiro Okazaki ${ }^{5}$ Hiroyuki Nakamura ${ }^{4}$ Shoichi \\ Koizumi $^{6}$ Akihiro Yachie ${ }^{7}$ Hisanori Umehara ${ }^{5}$ \\ ${ }^{1}$ Department of Physiology, Graduate School of Medical Science, Kanazawa University, Kanazawa, \\ 2Department of Environmental Physiology, School of Medicine, Shimane University, Shimane, \\ ${ }^{3}$ Department of Impairment Study, Graduate School of Medical Science, Kanazawa University, \\ Kanazawa, ${ }^{4}$ Department of Public Health, Graduate School of Medical Science, Kanazawa University, \\ Kanazawa, ${ }^{5}$ Department of Hematology and Immunology, Kanazawa Medical University, Kanazawa, \\ ${ }^{6}$ United Graduate School of Child Development, Graduate School of Medical Science, Kanazawa \\ University, Kanazawa, ${ }^{7}$ Department of Pediatrics, Graduate School of Medical Science, Kanazawa \\ University, Kanazawa
}

\section{Key Words}

Heat acclimation $\cdot$ Heat tolerance $\cdot$ Heat shock proteins $\cdot$ Aquaporins $\cdot$ Cell growth $\cdot$ Cell morphology

\footnotetext{
Abstract

The heat shock response has been extensively studied by a number of investigators to understand the molecular mechanism underlying the cellular response to severe heat stress (higher than $42^{\circ} \mathrm{C}$ ). But, body or tissue temperature increases by only a few degrees Celsius during physiological events. Therefore, the physiological cellular response to mild heat stress rather than severe heat stress is likely to be more important. Repeated exposure to hyperthermia for consecutive 5 days induces heat acclimation which is an adaptive physiological process in humans and animals. However, thus far, the effect of continuous exposure to heat stress on cells has not been fully evaluated. In this study, we investigated an adaptive physiological process that is induced in culture cells by continuous exposure to mild heat stress for 5 days. Exposure to heat activated p38-mitogen-activated protein kinase; inhibited cell growth without apoptosis; and increased the levels of HSPs and HSF-1 in mouse fibroblast cells. Interestingly, exposure to heat regulated the expression of aquaporins and induced morphological change. In a physiological sense, these results suggested that continuous exposure to mild heat stress for 5 days, in which heat acclimation is attained in humans and animals, might induce molecular adaptation to heat in cells.

Copyright (C) 2012 S. Karger AG, Basel

Naotoshi Sugimoto, M.D., Ph.D.

Department of Physiology, Graduate School of Medical science, Kanazawa University

13-1 Takara-machi, Kanazawa, Ishikawa, 920-8640 (Japan)

Tel. +81-76-265-2314, Fax +81-76-262-1866

E-Mail ns@med.kanazawa-u.ac.jp, nsns@staff.kanazawa-u.ac.jp
} 


\begin{tabular}{|c|c|c|}
\hline $\mathrm{Col}$ & Cell Physiol Biochem 2012;30:450-457 & \\
\hline and Binchemistry & $\begin{array}{l}\text { DOI: 10.1159/000339038 } \\
\text { Published online: July 06, } 2012\end{array}$ & $\begin{array}{l}\text { O } 2012 \text { S. Karger AG, Basel } \\
\text { www.karger.com/cpb }\end{array}$ \\
\hline
\end{tabular}

\section{Introduction}

The heat shock response has been extensively studied by a number of investigators to understand the molecular mechanism underlying the cellular response to heat stress. Although information about the heat shock response has contributed to the advancement of biological science, most studies focused largely on cellular responses to severe heat stress [1]. However, body or tissue temperature increases by only a few degrees Celsius during physiological events, ie, heat acclimation and febrile disease. Therefore, the physiological cellular response to mild heat stress rather than severe heat stress is likely to be more important.

Heat acclimation is an adaptive physiological process that occurs in humans and animals by repeated exposure to hyperthermia, such as at high ambient temperatures $[2,3]$. The primary benefit of heat acclimation is improved heat tolerance, evident by reduction in the incidence or severity of symptoms of heat illness, and increased work output concurrent with reduced cardiovascular, thermal, and metabolic strain. Research on heat acclimation has focused almost exclusively on the induction of this response. It is accepted that complete adaptation to heat stress occurs after 7 to 10 days and $75 \%$ of the adaptation are evident from 4 to 6 days. Indeed, a continuous 5-day exposure to heat stress significantly attenuated thermal strain and enhanced exercise capacity in the heat, and this finding concurs with those of previous reports in humans and animals [4-6].

Acute exposure to mild heat shock, but not severe heat shock, for less than $24 \mathrm{~h}$ has been shown to induce the synthesis of cyclin D1 [7], indicating G1 progression of the cell cycle. However, the effects of heat stress vary depending on the duration of the heat exposure [8]. Thus, the effect of continuous 5-day exposure to heat stress on cells is not yet evaluated.

In this study, we investigated the effects of exposure to mild heat stress for a 5-day continuous period, in which heat acclimation is attained in humans and animals, on cellular response, ie, cell growth, cell morphology, activation of mitogen-activated protein kinase (MAPK), and expression of heat shock proteins (HSPs) and aquaporins, in mouse fibroblast cells.

\section{Materials and Methods}

\section{Chemicals}

Dulbecco's modified Eagle's medium (DMEM) was obtained from Wako Pure Chemical Industries, Ltd (Osaka, Japan). Fetal bovine serum (FBS) was obtained from Invitrogen Corporation (Carlsbad, CA). Anti-p38 MAPK, anti-phospho-specific p38 MAPK (Thr180/Tyr182), anti-HSF1, anti-HSP90, anti-HSP70, anti- $\beta$-actin, horseradish peroxidase (HRP)-linked anti-rabbit IgG, and anti-mouse IgG were purchased from Cell Signaling Technology, Inc. (Danvers, MA). Anti-aquaporin4 was obtained from Millipore (Billerica, MA). Anti-aquaporin5 was obtained from Calbiochem (La Jolla, CA).

\section{Cell culture}

NIH3T3 mouse fibroblast cells were provided by Dr. Komine (Kanazawa University). The cells were maintained in DMEM containing $10 \% \mathrm{FBS}$ at $37^{\circ} \mathrm{C}$ in a $5 \% \mathrm{CO}_{2}$ incubator.

\section{Continuous exposure to mild heat stress}

Two $\mathrm{CO}_{2}$ incubators were prepared. One was kept at $37^{\circ} \mathrm{C}$ and the other was kept at $39.5^{\circ} \mathrm{C}$. NIH3T3 cells were seeded in several $60 \mathrm{~mm}$ or $100 \mathrm{~mm}$ dishes. After $24 \mathrm{~h}$ incubation at $37^{\circ} \mathrm{C}$, the cells were incubated at $37^{\circ} \mathrm{C}$ or $39.5^{\circ} \mathrm{C}$ in $5 \% \mathrm{CO}_{2}$ for $3 \mathrm{~h}, 24 \mathrm{~h}$ or 5 days. New preheated culture medium containing $10 \%$ FBS was replaced every 2 days. Cells grew in the logarithmic phase during the culture.

\section{Cell proliferation assay}

Cell proliferation was analyzed using the Cell Counting Kit 8 (Wako, Japan). NIH3T3 cells were seeded in 96-well plates at a density of $1 \times 10^{2}$ cells/well. After 24 -h incubation, the cells were divided into 2 groups and incubated at $37^{\circ} \mathrm{C}$ or $39.5^{\circ} \mathrm{C}$ for 5 days. At the end of 5 days of continuous passive warming, cells were 


\begin{tabular}{|c|c|c|}
\hline Collular & Cell Physiol Biochem 2012;30:450-457 & \\
\hline and Biochemistry & $\begin{array}{l}\text { DOI: 10.1159/000339038 } \\
\text { Published online: July 06, } 2012\end{array}$ & $\begin{array}{l}\text { (c) } 2012 \text { S. Karger AG, Basel } \\
\text { www.karger.com/cpb }\end{array}$ \\
\hline
\end{tabular}

allowed to recover at the standard culture temperature $\left(37^{\circ} \mathrm{C}\right)$ until their medium temperature returned to $37^{\circ} \mathrm{C}$, which required approximately $1 \mathrm{~h}$. Then, the cells were incubated with 10 -ì WST- 8 for $2 \mathrm{~h}$ at $37^{\circ} \mathrm{C}$. Absorbance of the colored formazan product produced by mitochondrial dehydrogenases in metabolically active cells was recorded at $450 \mathrm{~nm}$ as the background value. Cell proliferation was expressed as a percentage of absorbance obtained in treated wells relative to that in untreated (control) wells.

\section{Western blotting analysis}

Western blotting was performed as described previously [9]. Briefly, proteins were extracted from cells, and protein concentrations were determined by a protein assay. Equal amounts of protein were separated using 10\% sodium dodecyl sulfate-polyacrylamide gel electrophoresis (SDS-PAGE). The resolved proteins were transferred onto polyvinylidene fluoride (PVDF) membranes, which were incubated with primary antibodies (1:1000), followed by incubation with HRP-linked secondary antibodies (1:2000). The blots were developed using Immobilon Western Chemiluminescence HRP Substrate (Millipore, Billerica, MA).

DNA ladder analysis

To evaluate the apoptotic DNA fragments in the cells, DNA ladder analysis was performed by Apoptotic DNA Ladder Kit (Roche, Mannheim, Germany).

Heat shock treatment

The cells were exposed at $42^{\circ} \mathrm{C}$ for $30 \mathrm{~min}$ [10] following the 5 -day incubation at $37^{\circ} \mathrm{C}$ or $39.5^{\circ} \mathrm{C}$ in $5 \%$ $\mathrm{CO}_{2}$, and then returned and incubated at $37^{\circ} \mathrm{C}$ or $39.5^{\circ} \mathrm{C}$ in $5 \% \mathrm{CO}_{2}$ for $16 \mathrm{~h}$. After that, DNA ladder analysis was performed by Apoptotic DNA Ladder Kit (Roche, Mannheim, Germany).

Reverse transcription-mediated polymerase chain reaction analysis

To evaluate the expression pattern of aquaporin 1 (AQP1), AQP2, and AQP3 mRNA in the cells, reverse transcription-mediated polymerase chain reaction (RT-PCR) was performed as follows. Briefly, RNA was extracted from the cells and reverse transcribed by using the reverse transcriptase ReverTra Ace (TOYOBO, Tokyo, Japan). PCR-based subtype specific gene amplification for AQP1 and $\beta$-actin was performed with LA Taq (TAKARA, Tokyo, Japan) by using the following sets of primers: $5^{\prime}$-catgtacatcatcgcccagt-3' and 5' ccacagccagtgtagtcaat-3' for AQP1, 5'-gtcttctttggccttggctc-3' and 5'-gagagcattgacagccaggt-3' for AQP2, 5'agatgctccacatccgctac- $3^{\prime}$ and $5^{\prime}$-agatgggcagcttgatccag-3' for AQP3, and 5'-atggtgggtatgggtcagaag- $3^{\prime}$ and $5^{\prime}$ ctggggtgttgaaggtctcaa- $3^{\prime}$ for $\beta$-actin.

Statistical analysis

Statistical analyses were performed using Student's unpaired t-test. Single and double asterisks in figures indicate $\mathrm{p}<0.05$ and $\mathrm{p}<0.01$, respectively. All data are expressed as mean $\pm \mathrm{SEM}$.

\section{Results and Discussion}

Continuous 5-day exposure to mild heat stress induced HSP70, HSP90, and HSF-1 expression in NIH3T3 cells

Organisms have undergone natural selection in order to deal with the insults of thermal fluctuations in the ambient environment to obtain well-developed defense and adaptation machineries. When cells encounter heat stress, they provoke active responses such as inducing signal pathways and reprogramming gene expression to retune their internal milieu. The most well characterized heat shock response is induction of a highly conserved set of polypeptides termed as the heat shock proteins (HSPs). In vivo experiments have shown that HSP72 and HSP90 protein levels increase in several organs in mice exposed to the 5-day heat [6] and in peripheral blood mononuclear cells in humans [3]. Similar to the response in animals, in vitro studies showed that 5-day exposure to mild heat stress increased the levels of HSP70 and HSP90 (Fig. 1A, 1B).

Heat stress-induced HSPs expression is mediated by activation of the heat shock factor 1 (HSF-1). Next, we investigated the effect of 5-day exposure to mild heat stress on HSF- 


\begin{tabular}{ll|l} 
Cellular Physiology & \multicolumn{1}{c}{$\begin{array}{l}\text { Cell Physiol Biochem 2012;30:450-457 } \\
\text { and Biochemistry }\end{array}$} & $\begin{array}{l}\text { DOI: 10.1159/000339038 2012 S. Karger AG, Basel } \\
\text { aublished online: July 06, 2012 }\end{array}$ \\
\cline { 2 - 3 } & Sugimoto/Shido/Matsuzaki et al: Cellular Heat Acclimation
\end{tabular}

Fig. 1. Upregulation of HSF1, HSP90, and HSP70 protein expression (A, B), and activation of p38-MAPK (C, D) after a continuous 5-day exposure to mild heat stress in NIH3T3 cells. (A) Cell lysates were obtained after 5-day incubation of $39.5^{\circ} \mathrm{C}$ or $37^{\circ} \mathrm{C}$ and $\mathrm{HSF} 1$, HSP90, and HSP70 protein expression were examined by Western blot as described Materials and Methods. HSF1, HSP90, and HSP70 protein expression were increased after heat exposure. (B) Results are means \pm SE of 3 independent experiments. *Statistically significant values had $P<0.05$ compared with the values of incubation at $37^{\circ} \mathrm{C}$. ${ }^{* *}$ Statistically significant values had $P<0.01$ compared with the values of incubation at $37^{\circ} \mathrm{C}$. (C) Cell lysates were obtained after 5 -day incubation of $39.5^{\circ} \mathrm{C}$ or $37^{\circ} \mathrm{C}$ and phosphorylation of p38-MAPK was examined by Western blot. p38-MAPK was phosphorylated in treatment of heat exposure. (D) Results are means \pm SE of 3 independent experiments. ${ }^{* *}$ Statistically significant values had $P<0.01$ compared with the values of incubation at $37^{\circ} \mathrm{C}$.

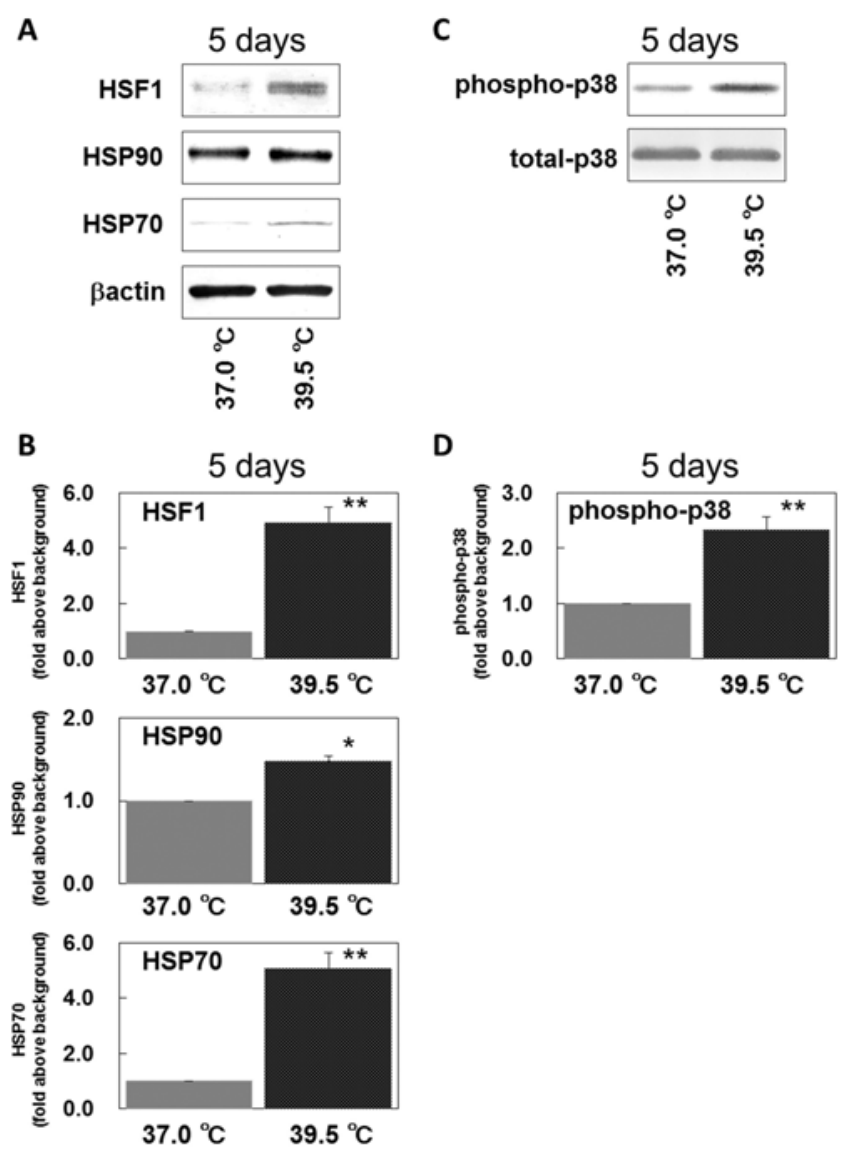

1 in NIH3T3 cells. As expected, the expression of HSF-1 significantly increased after 5-day exposure to mild heat stress (Fig. 1A, 1B). These results indicate that continuous 5-day exposure to mild heat stress directly regulates HSPs levels, as well as heat acclimation of animals as previously been reported [6].

Continuous 5-day exposure to mild heat stress activated p38-MAPK in NIH3T3 cells

Hyperthermia or heat shock has been shown to induce a stress response that triggers the activation of a superfamily of protein kinases that are ubiquitously expressed and highly conserved throughout evolution, namely, the mitogen-activated protein kinases (MAPKs). Among the MAPK subfamilies, p38-MAPK is collectively known as the principal stressactivated protein kinases [11]. The kinase transduces extracellular stimuli to the cytoplasm or nucleus, where it interacts with the respective substrates, eliciting a cellular response favoring survival or apoptosis. In the present study, continuous 5-day exposure to heat stress increased the phosphorylation of p38-MAPK in NIH3T3 cells, indicating the activation of p38-MAPK (Fig. 1C, 1D). The observed p38-MAPK activation may serve a protective role against thermal stress, as has previously been reported in other experimental models under variable forms of stress [11].

3-hour or 24-hour exposure to mild heat stress affected the expression of HSP70 and HSP90, and activated p38-MAPK in NIH3T3 cells

The effects of heat stress vary depending on the duration of the heat exposure [8]. Thus, we investigated the effects of exposure to mild heat stress for 3-hour or 24-hour on cellular response in mouse fibroblast cells. 3-hour exposure to mild heat stress significantly increased the level of phospho-p38 MAPK, but not the expression of HSP90 and HSP70 (Fig. 2A, B). While 24-hour exposure to mild heat stress significantly increased the expression of HSP90 and HSP70, and the level of phospho-p38 MAPK (Fig. 2C, D). However, the enhancement of 


\section{Cellular Physiology and Biochemistry

\begin{tabular}{|c|c|}
\hline \multicolumn{2}{|c|}{ Cell Physiol Biochem 2012;30:450-457 } \\
\hline DOI: $10.1159 / 000339038$ & (C) 2012 S. Karger AG, Basel \\
\hline Published online: July 06, 2012 & www.karger.com/cpb \\
\hline
\end{tabular}

Fig. 2. Effect of 3-hour (A, B) and 24hour (C, D) exposure to mild heat stress on HSP90, and HSP70 protein expression, and activation of p38-MAPK in NIH3T3 cells. (A) Cell lysates were obtained after 3 -hour incubation of $39.5^{\circ} \mathrm{C}$ or $37^{\circ} \mathrm{C}$ and HSP90 and HSP70 protein expression and phosphorylation of p38-MAPK were examined by Western blot as described Materials and Methods. HSP90 and HSP70 protein expression were not affected after heat exposure, but p38-MAPK was phosphorylated in treatment of heat exposure. (B) Results are means \pm SE of 3 independent experiments. *Statistically significant values had $\mathrm{P}<0.05$ compared with the values of incubation at $37^{\circ} \mathrm{C}$. (C) Cell lysates were obtained after 24hour incubation of $39.5^{\circ} \mathrm{C}$ or $37^{\circ} \mathrm{C}$, and HSP90 and HSP70 protein expression and phosphorylation of p38-MAPK were examined by Western blot as described Materials and Methods. HSP90 and HSP70 protein expression, and the level of phosphorylation of p38-MAPK were increased after heat exposure. (D) Results are means \pm SE of 3 independent experiments. *Statistically significant values had $\mathrm{P}<0.05$ compared with the values of incubation at $37^{\circ} \mathrm{C}$.

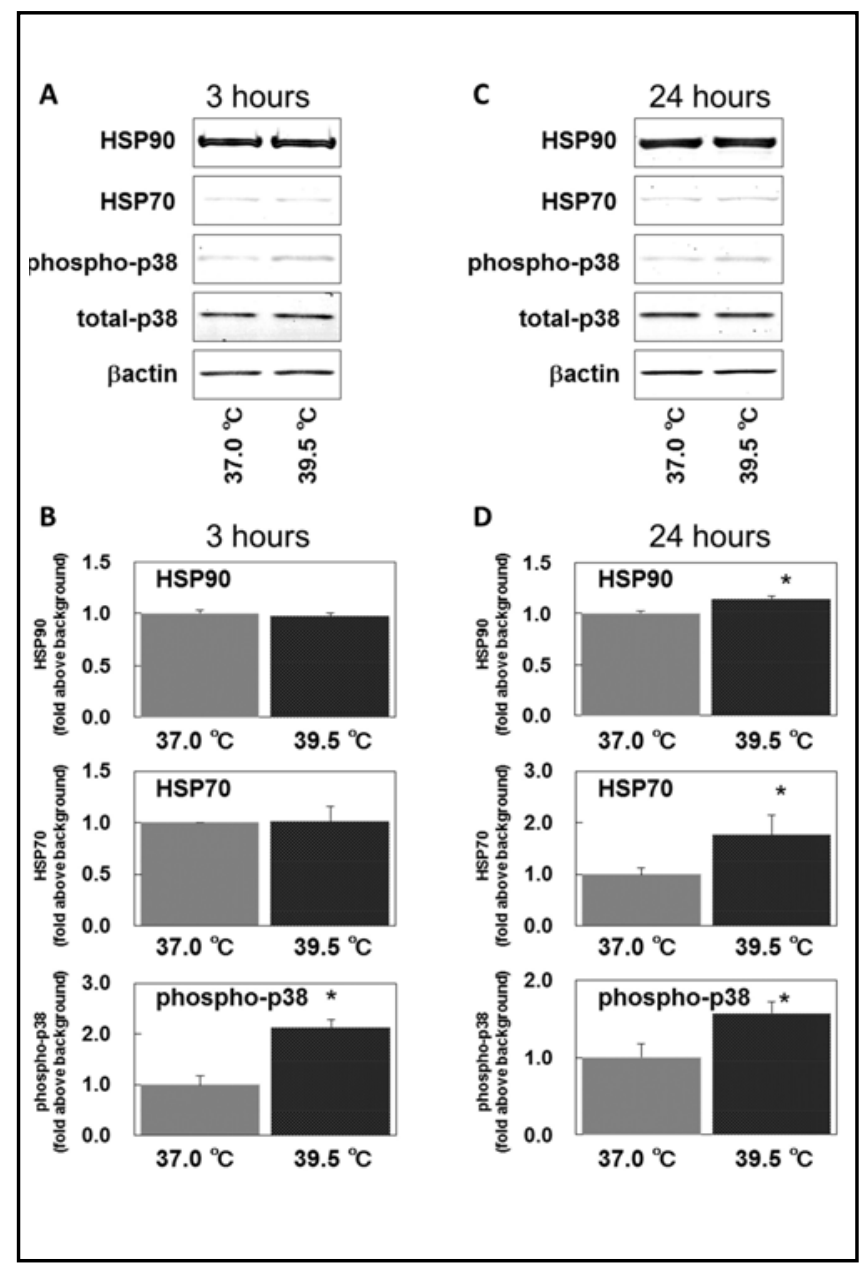

the expression of HSP90, HSP70, and phospho-p38 MAPK after 24-hour exposure to mild heat stress (the values of HSP90, HSP70, and phospho-p38 MAPK were $1.14 \pm 0.02,1.77$ $\pm 0.38,1.57 \pm 0.15$, respectively) were lower than those after 5 -day exposure to heat (the values of HSP90, HSP70, and phospho-p38 MAPK were $1.48 \pm 0.06,5.07 \pm 0.57,2.33 \pm 0.23$, respectively) (Fig. 1, 2). From these results, the expression of HSP90, HSP70, and phosphop38 MAPK after exposure to mild heat stress may increase in a time-dependent manner.

Continuous 5-day exposure to mild heat stress inhibited cell growth without the induction of apoptosis in NIH3T3 cells

Since there are reports of activation of p38-MAPK on our experimental model and with heat shock known to trigger apoptosis [12], we next tried to identify any features characteristic of cell growth and apoptosis. First, we investigated the cell viability of NIH3T3 cells after mild heat exposure for 5 -day using the Cell Counting Kit 8 . Cells were incubated at $37^{\circ} \mathrm{C}$ or $39.5^{\circ} \mathrm{C}$ for $5 \mathrm{~d}$ and then transferred to $37^{\circ} \mathrm{C}$ for an additional $1 \mathrm{~h}$, and cell proliferation was analyzed. As shown in Figure $3 \mathrm{~A}, 39.5^{\circ} \mathrm{C}$ heat treatment for 5 days markedly inhibited cell growth. After continuous 5-day exposure to heat stress, cells were incubated at $37^{\circ} \mathrm{C}\left(39.5^{\circ} \mathrm{C}\right.$ to $37^{\circ} \mathrm{C}$ ), and cell growth was analyzed again after 3 days. The growth of cells incubated from $39.5^{\circ} \mathrm{C}$ to $37^{\circ} \mathrm{C}$ was not different from that of cells incubated continuously at $37^{\circ} \mathrm{C}\left(37^{\circ} \mathrm{C}\right.$ to $37^{\circ} \mathrm{C}$ ) (data not shown). While caspases are the primary regulators and effectors of this form of programmed cell death; however, no cleavage of caspase 3-indicative of apoptosis was detected (Fig. 3B). Further studies are required in order to highlight the exact mechanism regulating this effect since the notion that caspases are not the sole effectors of apoptosis has already been established [13]. Therefore, we focus on the other key apoptotic events, DNA fragmentation. No fragmentation of DNA was detected (Fig. 3C). We concluded that cell 


\section{Cellular Physiology and Biochemistry

\begin{tabular}{|c|c|}
\hline \multicolumn{2}{|c|}{ Cell Physiol Biochem 2012;30:450-457 } \\
\hline DOI: $10.1159 / 000339038$ & (c) 2012 S. Karger AG, Basel \\
\hline Published online: July 06, 2012 & www.karger.com/cpb \\
\hline
\end{tabular}

Fig. 3. Mild heat stress attenuated the cell growth without caspase 3 cleavage and DNA fragmentation and heat shock-induced apoptosis in NIH3T3 cells. (A) Cell proliferation was analyzed using the Cell Counting Kit 8 (Wako, Japan) as described in Materials and Methods. Continuous 5-day exposure to mild heat stress $\left(39.5^{\circ} \mathrm{C}\right)$ inhibited cell growth in NIH3T3 cells. Results are means \pm SE of 6 independent experiments. ${ }^{* *}$ Statistically significant values had $P<0.01$ compared with the values of incubation at $37^{\circ} \mathrm{C}$. (B) Cell lysates were obtained after 5 -day incubation of $39.5^{\circ} \mathrm{C}$ or $37^{\circ} \mathrm{C}$ and caspase 3 protein expression was examined by Western blot as described in Materials and Methods. Cleavage of capsase 3 was not affected by heat exposure. Results are representative of 3 independent experiments. (C) DNA were obtained after 5-day incubation of $39.5^{\circ} \mathrm{C}$ or $37^{\circ} \mathrm{C}$ and DNA fragmentation was examined by DNA ladder analysis as described in Materials and Methods. DNA fragmentation was not affected by heat

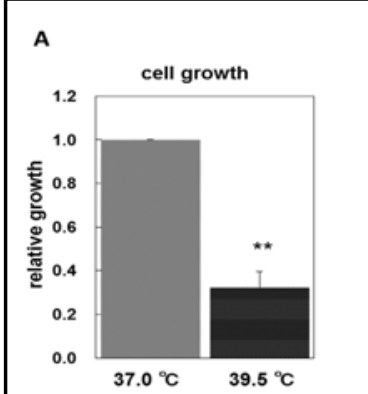

C
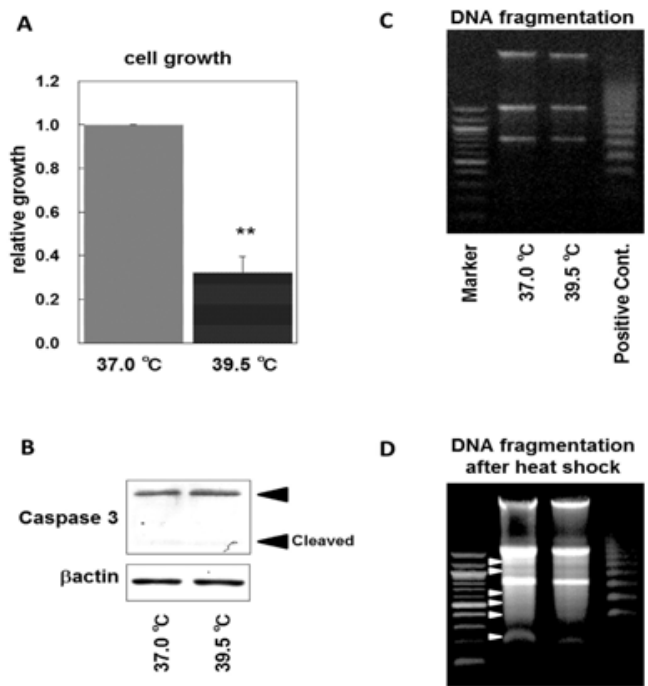

D

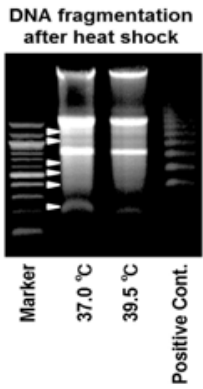

exposure. Results are representative of 3 independent experiments. (D) DNA were obtained after heat shock following the 5 -day incubation of $39.5^{\circ} \mathrm{C}$ or $37^{\circ} \mathrm{C}$ and DNA fragmentation was examined by DNA ladder analysis as described in Materials and Methods. Arrowhead indicates a DNA fragment. The fragmentation of DNA in cells incubated at $37^{\circ} \mathrm{C}$ increased and became more evident compared with that in cells incubated at $39.5^{\circ} \mathrm{C}$ for 5 days. Results are representative of 3 independent experiments.

apoptosis might be not responsible for the inhibition of cell growth during 5-day exposure to mild heat stress in NIH3T3 cells (Fig. 3A, 3B, 3C). These results suggested that 5-day exposure to mild heat stress might induce inhibition of cell growth without cell apoptosis.

Continuous 5-day exposure to mild heat stress attenuated heat shock-induced apoptosis in NIH3T3 cells

Next, we examined whether continuous 5-day exposure to heat improves heat tolerance in the NIH3T3 cells. The cells were incubated at $42^{\circ} \mathrm{C}$ for $30 \mathrm{~min}$ (heat shock) following the 5 -day incubation at $37^{\circ} \mathrm{C}$ or $39.5^{\circ} \mathrm{C}$, and then returned to $37^{\circ} \mathrm{C}$ or $39.5^{\circ} \mathrm{C}$. DNA were obtained $16 \mathrm{~h}$ after heat shock and DNA fragmentation was examined by DNA ladder analysis as described in Materials and Methods. Although DNA fragmentation were detected in both cells incubated at $37^{\circ} \mathrm{C}$ and $39.5^{\circ} \mathrm{C}$, the fragmentation of DNA in cells incubated at $37^{\circ} \mathrm{C}$ increased and became more evident compared with that in cells incubated at $39.5^{\circ} \mathrm{C}$ for 5 days (Fig. 3D). The result suggested that continuous 5-day exposure to mild heat stress may attenuate heat shock-induced apoptosis and improve heat tolerance in NIH3T3 cells.

Continuous 5-day exposure to mild heatstress regulated the cell morphology and expression of aquaporins in NIH3T3 cells

Microscopic examination indicated that continuous 5-day exposure to heat stress affected the cell morphology; the cells showed spreading and were elongated (Fig. 4A). Cells were incubated at $37^{\circ} \mathrm{C}\left(39.5^{\circ} \mathrm{C}\right.$ to $\left.37^{\circ} \mathrm{C}\right)$; subsequently, cell morphology was analyzed after 3 days. The cell morphology of cells incubated at $39.5^{\circ} \mathrm{C}$ to $37^{\circ} \mathrm{C}$ was not different from that of cells incubated continuously at $37^{\circ} \mathrm{C}\left(37^{\circ} \mathrm{C}\right.$ to $37^{\circ} \mathrm{C}$ ) (data not shown).

Aquaporins are an additional example of molecules involved in tolerance [14]. These proteins serve as channels for water and small solutes to pass through the cell membrane [15]; therefore, genes encoding aquaporins serve an important function because water movement across cellular membranes must be drastically increased during both dehydration and 


\section{Cellular Physiology and Biochemistry

Fig. 4. Mild heat stress regulated cell morphology and expression of aquaporins in NIH3T3 cells. (A) The cells were incubated at $39.5^{\circ} \mathrm{C}$ or $37^{\circ} \mathrm{C}$ for constitutive 5 days. Cells in $39.5^{\circ} \mathrm{C}$ showed spreading and became elongated. White bar indicates $20 \mu \mathrm{m}$. Results are representative of 3 independent experiments. (B) The total RNA was obtained after 5-day incubation of $39.5^{\circ} \mathrm{C}$ or $37^{\circ} \mathrm{C}$, and $\mathrm{AQP} 1, \mathrm{AQP} 2$, and AQP3 mRNA expression were examined by RT-PCR as described in Materials and Methods. AQP1 and AQP2, but not AQP3, mRNA expression were increased after heat exposure. Results are representative of 3 independent experiments. Results are means \pm SE of 3 independent experiments. *Statistically significant values had $P<0.05$ compared with the values of incubation at $37^{\circ} \mathrm{C}$. (C) Cell lysates were obtained after 5-day incubation of $39.5^{\circ} \mathrm{C}$ or $37^{\circ} \mathrm{C}$, and AQP4 and AQP5 protein expression were examined by Western blot as

A

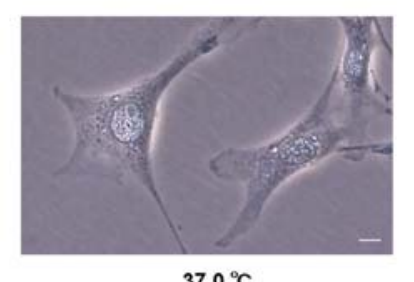

$37.0^{\circ} \mathrm{C}$
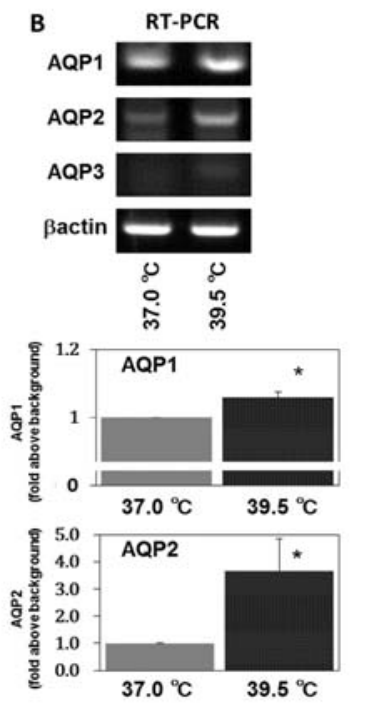

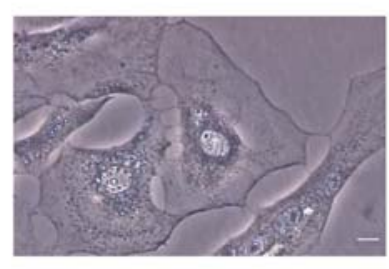

$39.5^{\circ} \mathrm{C}$

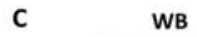

AQP4

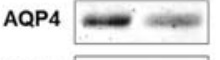

AQP5

Bactin
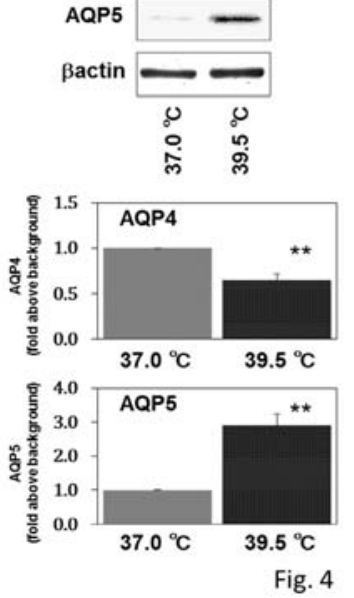

described in Materials and Methods. AQP4 protein expression was decreased, while AQP5 protein expression was increased after heat exposure. The results are representative of 3 independent experiments. Results are means \pm SE of 3 independent experiments. ${ }^{* *}$ Statistically significant values had $P<0.01$ compared with the values of incubation at $37^{\circ} \mathrm{C}$.

rehydration to maintain osmotic balance. Temperature changes may alter osmotic pressure. Thus, we evaluated the expression of aquaporins before and after heat exposure in NIH3T3 cells. Two antibodies, anti-AQP4 and anti-AQP5 antibodies, were available for detection of mouse AQP4 and AQP5, respectively. The other 3 AQPs, namely, AQP1, AQP2, and AQP3, were evaluated by RT-PCR. AQP3 was below the limit of detection of our study, but other AQPs were detectable (Fig. 4B, 4C). AQP1, AQP2, and AQP5 levels were increased after 5-day heat exposure (Fig. 4B, 4C), while AQP4 level was decreased after heat exposure (Fig. 4C). 3-hour or 24-hour heat exposure did not affect the expression of AQPs (data not shown). These results suggested that heat exposure regulates the expression of AQPs to adapt heat stress in cells. However, the details regarding the mechanisms and role underlying heat regulation of AQPs are still unknown. Further studies are required to determine the mechanism and role of heat-dependent regulation of AQPs expression in fibroblast cells.

\section{Conclusion}

Kaspler and Horowitz have shown that neurohumoral (extracellular) factors might attenuate the originating cellular responses elicited by the persistent heat stress in the heatacclimated animals [8]. Hence, it is important to evaluate the direct effect of persistent heat stress on the cells. In this study, our results suggest that continuous 5-day exposure to mild heat stress may induce molecular adaptation to heat in culture cells, as well as in humans and animals. 


\begin{tabular}{|c|c|c|}
\hline $\mathrm{Col}$ & Cell Physiol Biochem 2012;30:450-457 & \\
\hline and Binchemistry & $\begin{array}{l}\text { DOI: 10.1159/000339038 } \\
\text { Published online: July 06, } 2012\end{array}$ & $\begin{array}{l}\text { O } 2012 \text { S. Karger AG, Basel } \\
\text { www.karger.com/cpb }\end{array}$ \\
\hline
\end{tabular}

\section{Abbreviations}

AQP (aquaporin); HSF (heat shock factor); HSP (heat shock protein); MAPK (mitogenactivated protein kinase).

\section{Acknowledgements}

This work was supported in part by Grants-in-Aid for Science and Culture from the Ministry of Education, Culture, Sports, Science, and Technology of Japan.

\section{References}

1 Richter K, Haslbeck M, Buchner J: The heat shock responses: Life on the verge of death. Mol Cell 2011;40:253-266.

2 Sawka MN, Young AJ, Rock PB, Lyons TP, Boushel R, Freund BJ, Muza SR, Cymerman A, Dennis RC, Pandolf $\mathrm{KB}$, Valeri CR: Altitude acclimatization and blood volume: effects of exogenous erythrocyte volume expansion. J Appl Physiol 1996;81:636-642.

3 McClung JP, Hasday JD, He JR, Montain SJ, Cheuvront SN, Sawka MN, Singh IS: Exercise-heat acclimation in humans alters baseline levels and ex vivo heat inducibility of HSP72 and HSP90 in peripheral blood mononuclear cells. Am J Physiol Regul Integr Comp Physiol 2008;294:R185-191.

4 Garrett AT, Goosens NG, Rehrer NJ, Patterson MJ, Cotter JD: Induction and decay of short-term heat acclimation. Eur J Appl Physiol 2009;107:659-670.

5 Horowitz M, Konesh E: Molecular signals that shape the integrative responses of the heat-acclimated phenotype. Med Sci Sports Exerc 2010;42:2164-2172.

6 Sareh H, Tulapurkar ME, Shah NG, Singh IS, Hasday JD: Response of mice to continuous 5-day passive hyperthermia resembles human heat acclimation. Cell Stress Chaperones 2011;16:297-307.

7 Han SI, Oh SY, Jeon WJ, Kim JM, Lee JH, Chung HY, Choi YH, Yoo MA, Kim HD, Kang HS: Mild heat shock induces cyclin D1 synthesis through multiple Ras signal pathways. FEBS Lett 2002;515:141-145.

8 Kaspler P, Horowitz M: Heat acclimation and heat stress have different effects on cholinergic muscarinic receptors. Ann N Y Acad Sci 1997;813:620-627.

9 Miwa S, Sugimoto N, Shirai T, Hayashi K, Nishida H, Ohnari I, Takeuchi A, Yachie A, Tsuchiya H: Caffeine activates tumor suppressor PTEN in sarcoma cells. Int J Oncol 2011;9:465-472.

10 Kondo T, Matsuda T, Tashima M, Umehara H, Domae N, Yokoyama K, Uchiyama T, Okazaki T: Suppression of heat shock protein-70 by ceramide in heat shock-induced HL-60 cell apoptosis. J Biol Chem 2000;275:8872-8879.

11 Hagemann C, Blank JL: The ups and downs of MEK kinase interactions. Cell Signal 2001;13:863-875.

12 Creagh EM, Sheehan D, Cotter TG: Heat shock proteins--modulators of apoptosis in tumour cells. Leukemia 2000;14:1161-1173.

13 Regula KM, Kirshenbaum LA: Apoptosis of ventricular myocytes: a means to an end. J Mol Cell Cardiol 2005;38:3-13.

14 Philip BN, Yi SX, Elnitsky MA, Lee RE Jr: Aquaporins play a role in desiccation and freeze tolerance in larvae of the goldenrod gall fly, Eurosta solidaginis. J Exp Biol 2008;211:1114-1119.

15 Campbell EM, Ball A, Hoppler S, Bowman AS: Invertebrate aquaporins: a review. J Comp Physiol B 2008;178:935-955. 